\title{
A BREATH OF FRESH AIR: ECO-CONSCIOUSNESS IN MARY BARTON AND JANE EYRE
}

\author{
By Margaret S. Kennedy
}

You can vitiate the air by your manner of life, and of death, to any extent. You might easily vitiate it so as to bring such a pestilence on the globe as would end all of you. . . [E]verywhere, and all day long, you are vitiating it with foul chemical exhalations; and the horrible nests, which you call towns, are little more than laboratories for the distillation into heaven of venomous smokes and smells, mixed with effluvia from decaying animal matter, and infectious miasmata from purulent disease.

YOU CAN CONTINUE TO THOUGHTLESSLY pollute, Ruskin warns his readers, but in so doing you will destroy the earth and end your own existence. Six years earlier, in 1865, Ruskin coined the term "dis-ease" to denote a clear link between ill-being and environmental detachment. ${ }^{1}$ He yoked physical and mental health, elucidating " $[\mathrm{h}]$ ow literally that word DisEase, the Negation and impossibility of Ease, expressed the entire moral state of our English Industry and its Amusements!" ("Of Kings' Treasuries” 282). For Ruskin, nineteenth-century mills and factories, despite promising consumer satisfaction, made comfort impossible by endlessly producing frivolous, disposable goods, and thus waste. This needless consumption, a symptom of industry, produced an ignorance of true needs. Dis-ease, mental and bodily discomfort, resulted from alienation from the ecosystem, the networks of dependence between all species, and that estrangement blinded human beings to their actual role in the environment. While Ruskin focused on urban toxicity, the toxic ideological separation between humans and their environment impacted all spaces, a concern that several Victorian writers raised decades earlier than he did. This article traces the salutary cultural anxiety over improper sanitation and contaminants in two popular mid-nineteenth-century novels that demonstrate the effects of anthropogenic pollution in urban and rural environments, respectively. Published almost exactly one year apart, both Elizabeth Gaskell's Mary Barton (1848) and Charlotte Brontë's Jane Eyre (1847) invoke what I call eco-consciousness in their description of urban and rural filth, portrayed as both visible and invisible toxins. Gaskell uncovers urban pollution in plain sight, going beyond smell to expose the causes of toxicity, while Brontë challenges the belief in the country as a safe haven from pollution, 
going beyond beauty to expose rural toxicity. Characters suffer physical disease and mental dis-ease resulting from a poor understanding of ecological relationships. Reading Jane Eyre alongside Mary Barton accentuates Brontë's use of eco-consciousness to expose the hidden dangers of rural pollution that resulted from the very types of urban toxicity that Gaskell identifies.

\section{Beyond Miasma: Eco-Consciousness and Synesthesia}

IN “THE WHITE THORN BLOSSOM,” Ruskin follows a precedent set at mid-century, employing the familiar language of miasma ("foul," "venomous smokes and smells"), which focuses on sensory evidence of toxicity, to urge Victorians to reform their reckless "manner of life": wasteful consumption and unchecked pollution. Ruskin points to toxic behavior apathy towards the physical environment - and the literal toxins introduced thereby. This attention to pollution indicates the beginning of an ecologically conscious, or eco-conscious, discourse in Victorian fiction, which called for reformed relations between human beings and their habitats. I define eco-consciousness as teleological illustrations of actual ecological relationships, often involving pollution, designed to raise awareness and inspire real-world action.

Gaskell sets her first novel Mary Barton in Manchester to expose the consequences of industrial toxicity on health, chronicling the increasing depression of a cotton mill worker and his peers. ${ }^{2}$ While Gaskell's novel provides a familiar case study of urban horrors, Brontë's Jane Eyre presents its eponymous heroine traveling between rural locations as she awakens to anthropogenic pollution, interrogating the myth of pristine countryside. Brontë unveils both the urban horrors that infect rural spaces and the filth originating from unsanitary rural environments. Taken together, these two novels make pestilence visible and demonstrate a shared, eco-conscious vocabulary that reflects their authors' awareness of the need to reduce harm to the environment.

The Victorians understood toxicity through miasma theory, the belief that dangerous diseases such as malaria, cholera, typhus, typhoid, and even chlamydia originated in poisonous vapor or mist filled with particles from decomposed matter (miasmata) that caused illnesses. In 1846, Edwin Chadwick insisted to a Parliamentary committee that, "All smell is disease": foul odors did not merely point to a source of disease, they were the source (Metropolitan Sewage Committee 651). With the popularization of discoveries by Pasteur and Koch in the late nineteenth century, the germ theory of disease gained credence. ${ }^{3}$ Nevertheless, throughout the century, popular discourse continued to use miasmic language to describe causes of disease because its sensory language was often more effective in curbing unsanitary practices than the fear of invisible contaminants. A type of eco-conscious discourse, miasmic language functions as toxic discourse, which, as defined by Lawrence Buell, expresses "anxiety arising from perceived threat of environmental hazard due to chemical modification by human agency," "an interlocked set of topoi" resulting from cultural anxiety rather than the concerns of a specific author $(31,30) .{ }^{4}$ While Buell acknowledges that versions of toxic discourse previously existed, he insists that "never before the late twentieth century has it been so vocal, so intense, so pandemic, and so evidentially grounded" (31), particularly because of the now universal threat of chemical contamination.

Nevertheless, a study of Victorian literature reveals that, rather than merely alleging the risks posed by environmental contaminants, the realist novel presents cause-and-effect 
sequences between pollution and illness. As the prevailing genre of fiction for much of the nineteenth century, the realist novel disseminated toxic discourse equally, if not more, pandemically than literature from 1960 onwards. In mainstream literature, miasma theory became a lexicon that privileged sensory evidence of pollution in order to generate national awareness of not only visible or olfactory pollution, but to diagnose dis-ease, laying the foundation for more organized activism at the end of the century. ${ }^{5}$ The modern ecocritic Wendell Berry has theorized dis-ease as a sense of uneasiness and alienation when we exist separately from our natural environments. Dis-ease, as opposed to health, "makes us conscious not only of the state of our health but of the division of our bodies and our world into parts" (144). Though the concept has become part of ecocritical discourse, Berry does not cite Ruskin as its originator, which is one small example of the omission of Victorian environmental perspectives in contemporary ecocriticism. It is important to note that this modern understanding of dis-ease has Victorian roots. The expressive economies of dis-ease are not just symptoms of realities outside the texts in question - signs of what readers fail to comprehend in their own world - but exist within an active and inclusive set of formal and conceptual strategies in the period. Even before Ruskin, Octavia Hill, and William Morris, all of whom are generally acknowledged as proto-environmentalists, were directing attention to this reality, realist novelists began shaping eco-consciousness with references to damp and noxious rural atmospheres, such as Marney in Benjamin Disraeli's Sybil (1845), and the ubiquitous fog that rolls through Charles Dickens's London in Bleak House (1852-53). Novelists at mid-century directly addressed the deterministic influence of nonhuman nature. Responding to other writers in other disciplines (including politicians, public health officials, and journalists), novelists amplified concerns about environmental problems, which found distinct expression in fiction.

While Blue Books recorded horrendous working conditions and improper sanitation, novels often elaborated on these instances in vivid detail for a wider audience. The novel, designed to awaken sympathy and consciousness, found its way into the typical Victorian home and creatively, but forcefully, opened readers' eyes. The primary perceptual feature of eco-consciousness is the emphasis on vision: rendering visible the less apparent conditions of dis-ease, often through synesthesia, describing unseen disease through olfactory sensation for example. ${ }^{6}$ A reader, of course, cannot actually "smell" a description, but by overwhelming the imagination with graphic detail, miasmic language stimulates visceral reactions. Just as John Barton and George Wilson find themselves physically overpowered by fetid odors when entering a home in a Manchester slum, readers may also find themselves recoiling.

Many authors often substituted one sense for the other as a means of concretely representing filth, frequently referring to the "damp," "foul," or "pestilent[ial]" "smokes and smells" plaguing the environment. This miasmic language, employed by Ruskin in "The White Thorn Blossom," characterizes a shared language that rhetorically reconceives toxicity as man-made, even miasma, which, although organic, is tied to human obliviousness and recklessness. I expand Buell's definition of toxic discourse to include toxic organic pollutants like excrement and the bacteria and insects it nourishes. While all organisms modify their environment, and excrement is essentially "natural" and unavoidable pollution, eco-conscious Victorians such as Gaskell and Brontë reveal how human beings become an environmental threat when they overwhelm their habitat by maintaining an ideological separation between humanity and nature that condones reckless environmental impact. Miasmic language gets under the skin, opening readers' eyes to anthropogenic 
pollution and their concomitant vulnerability to contagion; but more than merely pointing out literal toxicity, this linguistic strategy promotes a larger eco-consciousness that attunes the reader to the general risk of attempting to subordinate the nonhuman environment.

As George Eliot famously wrote in Adam Bede (1859), a novelist's duty is to hold up a "mirror" to things as they are (164-65; bk. 2, ch. 17), rendering realism a moral imperative. Earnestly confronting the reader with true though unfamiliar or uncomfortable situations potentially stimulates sympathy and, in turn, prompts action to remedy serious social problems. Miasmic language exposes the risk of toxic diffusion, and its emphasis on human agency implies that pollution can be controlled. Novelists penned their graphic portrayals of filth to shock readers into eco-consciousness and a realization of their vulnerability to pollution. Novels position the reader as judge, weighing the evidence presented by the novel, which inspires opposition to unresponsive powers. Miasma's indiscriminate reach affects all people and places, and, just as miasma transgresses boundaries, novelists who employ miasmic language bring the reality of pollution into the middle-class home. It reveals that cleansing the grimiest places not only serves the underprivileged, it protects the health of all. This eco-consciousness points to real and hazardous conditions exposed in Gaskell's and Brontë's influential novels to which I now turn.

\section{Beyond Smell: Urban Toxicity}

AS MARY BARTON EMBARKS on her first journey away from home, she looks out the railway car window to see "the factory-chimneys, and the cloud of smoke which hovers over Manchester" (283; ch. 26). These chemical exhalations, a familiar sight to Mary, characterize the city, and the smokestacks responsible for the omnipresent haze sharpen Gaskell's focus on the consequences of industrialization in her first novel, Mary Barton. In many ways, we may consider her novel a case study of urban toxicity since her industrial fiction homes in on anthropogenic pollution engendered by factories, overcrowding, and poor sanitation, themes common to the social problem novel. In order to express her sympathy for the "care-worn men, who looked as if doomed to struggle through their lives in strange alternations between work and want" (3; Preface), Gaskell deliberately sets the scene in her hometown of Manchester, explaining in the novel's preface that she put aside her original intention to write a rural story. Though she primarily addresses the misunderstanding between masters and men during the Hungry Forties, her prefatory justification indicates an acute awareness of the health risks that come with living in an urban environment through the ever-present contrast between city and country. ${ }^{7}$ Gaskell's two ideological investments, giving voice to the laboring classes and demonstrating toxicity, coalesce into an inclusive mimetic ideal of environmental justice. In other words, she heralds the current social movement exposing the unequal toxic burden shouldered by minorities and advocating fair distribution of environmental benefits. ${ }^{8}$ The "great cities" emerging in the Victorian age became the focal point for toxic discourse, the ongoing public discussion of pollution, not because rural areas were especially clean, but because the cities underwent continual expansion. For instance, the population of London doubled between 1801 and 1841, nearly tripling by 1861. "Cancer" became the favorite word to describe the unchecked growth of cities in the late nineteenth century (Briggs 81). Even while symbolizing Victorian progress and ingenuity, towns were "regarded by many as the inevitable nexus of disease and premature death" (Wohl 3). In the 1840s, a column 
of smoke extending for twenty to thirty miles hung around London, and Gaskell presents a similar picture of Manchester when Mary, leaving the city, wistfully looks back towards a city enshrouded in smoke. ${ }^{9}$

Mary's description of the "manner of life" befouling Manchester as she gazes at the factory-chimneys anticipates Ruskin's 1871 accusation that rampant industrialism "vitiates" the air. The winter of 1840 depresses the spirits of Manchester's residents: "a bitter black frost had lasted for many weeks. . . . Houses, sky, people, and everything looked as if a gigantic brush had washed them all over with a dark shade of Indian ink" (Gaskell 4445 ; ch. 5). Countering expectations of a white winter, the "black" frost startles us into an awareness of Manchester's smoke. "Indian ink," a simple black ink made by combining soot and water, signifies that the city has literally been painted over with soot from domestic fires and industrial chimneys. Pollution perverts this scene, exacerbating conditions to the point that the residents remark on the strange new weather that persists well into spring. The unrelenting "keen east wind" resembles almost exactly Ruskin's observations of plaguewind forty years later in his two lectures on "The Storm Cloud of the Nineteenth Century" (1884), chronicling "peculiar" and previously unrecorded weather changes produced by environmental contamination. ${ }^{10}$ To emphasize the man-made causes of these weather events, Ruskin differentiates between rain-clouds that "do not darken the air, nor defile it, nor in any way mingle with it" and black plague-clouds, which "pollute the sky beyond and above them" (38). Deliberately conflating his terms, Ruskin uses "plague-wind" and "plague-cloud" synonymously with "storm-cloud" to indicate the unnatural and unprecedented severity of late nineteenth-century weather. While the "air itself is pure," when human beings "choose to mix up dirt with it," they "choke [themselves] with [their] own nastiness" (60). Rain, in fact, clears away the "deep, high filthiness of lurid, yet not sublimely lurid, smoke-cloud; dense manufacturing mist" (54-55). This fog - or, more accurately smog, as it would later come to be known as - results from reckless pollution, emerging from chimney-smoke and industrial furnaces that contaminate the air for miles around, recalling Mary's backwards glance towards Manchester. ${ }^{11}$ Gaskell's attention to soot and smoke rather than cold and frost indicate her concern over pollution engulfing the environment, anticipating Ruskin's storm cloud of the nineteenth century, which represents the era's fatal pollution that poisons the earth and its inhabitants. The hazardous conditions are not a product of natural changes; the frost's bitterness results from a toxic "manner of life."

Miasmic language, focusing on "foul" odors and filthy moisture, characterizes descriptions of the Victorian city or poor rural areas from novels and historical accounts, deliberately generating anxiety over pollution and then transforming this anxiety into a social problem. ${ }^{12}$ The most prevalent term, "filth," signaling both literal and figurative toxicity, became distinct from "dirt," a less condemnatory word. ${ }^{13}$ By acknowledging that filth was an issue that required immediate reform, Victorians "invented pollution," argues Peter Thorsheim (2). "Dust" came to mean excrement or litter. Fog was frequently described as "yellow," "rusty," or "brown," transforming the phenomenon into an artificial one: vapor made toxic by human activity. "Damp" coupled with "stagnant" often denoted toxic moisture produced by bodily fluids or mud festering in close quarters. Interestingly, novelists emphasized vision - the physical manifestation of smells or microscopic contaminants even while calling attention to odors; in other words, through synesthesia, they creatively embodied invisible risks as noxious clouds or "venomous" vapors. This eco-conscious vision characterizes the well-known scene in Mary Barton wherein John Barton and George Wilson 
visit the Davenport's cellar on Berry Street to nurse an unemployed, fever-stricken mill worker. The street

was unpaved; and down the middle a gutter forced its way, every now and then forming pools in the holes with which the street abounded. Never was the old Edinburgh cry of Gardez l'eau! more necessary than in this street. As they [Wilson and Barton] passed, women from their doors tossed household slops of every description into the gutter; they ran into the next pool, which overflowed and stagnated. (58-59; ch. 6)

The verb "overflow" uncovers the excess that creates a breeding ground for disease: excess population and excess waste. "Pools" of sewage accumulate as inhabitants empty chamber pots directly into the street. Though a "pool" typically denotes still, fresh water, Gaskell defamiliarizes the word as she describes unnatural formations, generating the salutary anxiety indicative of eco-consciousness. This reversal of traditional rhetoric drawn from natural history, which reveals environmental wonders, effectively startles readers into noticing environmental horrors. Human waste mingles with innumerable "household slops" that fester in the gutter. Poured onto the unpaved road, these fluids create a toxic mud ideal for breeding infection. What are seemingly everyday words ("pools," "slops," "heaps") take on the quality of filth because they are used as euphemisms for excrement. Moisture dominates this scene. Sensory language invokes the physical presence of waste designed to arrest the reader's attention. Importantly, Gaskell shows the direct action of "toss[ing]" slop directly into the environment. To avoid stepping in the muck, residents use "[h]eaps of ashes" as "stepping-stones" (59; ch. 6), in effect piling industrial filth on top of human filth. Gaskell describes an area made "foul" by miasma emanating from the mixture of organic matter (e.g., feces, decaying food) and inorganic matter (e.g., ash, smoke), both of which humans dump into the environment. ${ }^{14}$ Her miasmic lexicon reveals how the Victorian "manner of life" creates this atmosphere that then appears unnatural and requiring reform. This ecoconsciousness, the larger thought process her rhetorical choices subtend, forces readers to confront their complicity in filth. Despite the ubiquity of venomous smoke and smells in the $1840 \mathrm{~s}$, legislators, interest groups, and the general public remained relatively apathetic to pollution, accepting grime as an everyday, but tolerable, nuisance.

Due to the prevailing belief in miasma theory in the first half of the century, the Victorians were relatively unconcerned with the appearance of filth: if smell caused disease, de-odorizing rivers or cesspools with large amounts of lime ostensibly eliminated risk. Many believed that the coal smoke clouding the air, blackening bricks and clothes, while choking the lungs "purified" the air by killing disease particles. As in Berry Street, residents used ashes and cinders to hide the piles of excrement in their yards and wore over-shoes to traverse the muddy, damp streets. To disrupt this apathy, Gaskell traces how the filth outside literally re-invades the home. Barton and Wilson confront the inescapable waste as they descend into the dank cellar:

After the account I have given of the state of the street, no one can be surprised that on going into the cellar inhabited by Davenport, the smell was so feetid as almost to knock the two men down. Quickly recovering themselves, as those inured to such things do, they began to penetrate the thick darkness of the place, and to see three or four little children rolling on the damp, nay wet brick floor, through which the stagnant, filthy moisture of the street oozed up. (60; ch. 6; my emphases) 
Gaskell's interjection, following her "account" of the street overflowing with waste, shows how the filth outside floods the cellar. The terms often used to describe the conditions of the street now describe the inner sanctum of the house, uncovering the anxiety over miasma's ability to cross boundaries. Typical of miasmic explanations of disease, the smell threatens to overpower the men, yet the "wet" brick floor presents more concern. Gaskell emphasizes the moisture of the scene once again to underscore the physical presence of filth beyond odor; though she relies on miasmic language familiar to her readers, her focus on the physicality of the contaminants recognizes the shortcomings of miasma theory: odor is simply symptomatic of other threats. The men immediately feel physical and mental discomfort upon entering the cellar; they are struck with dis-ease, the uneasiness that Ruskin describes arising out of foul conditions. Their eyes must "penetrate the thick darkness" to allow the sources of the smell, of contagion, to come into focus. "Dampness" becomes a euphemism for effluvia, as the floor is not wet with foul water but with the feces seeping down from the street, which the children roll in like animals. Wilson opens a door within the Davenport's home, "but only for an instant: it led into a back cellar, with a grating instead of a window, down which dropped the moisture from pigsties, and worse abominations. It was not paved; the floor was one mass of bad smelling mud" (64; ch. 6). One can imagine Wilson's instant reflex to shut the door in disgust. By this point, the reader knows the "mud" is excrement. The Davenports' back room, despite increasing their rent, is unfit for man or beast and infects the unventilated residence with its fumes. That the men remain "inured" to this filth indicates that such lodgings and such behavior are not isolated incidents. Gaskell's reader, however, unlikely so desensitized, will feel the full force of the miasmic language, instigating a larger risk perception as they realize that the men leave the odors behind, but carry the invisible germs with them out into the world. Though germ theory would not supersede miasma theory until late in the nineteenth century, Gaskell's attention to the tactile quality of filth and the ways in which contagion is transmitted through proximity indicates a deeper understanding of how illness spreads independently of odor alone.

This chapter, "Poverty and Death," reveals both Gaskell's intention to expose the harsh living conditions of the poor and her awareness of toxicity. The miasmic words "filth," "fetid," and "stagnant" work together to create eco-conscious discourse that reveals a clear causal relationship between living conditions and disease. Gaskell's graphic descriptions leave no room to question the causes of ill health, ascribing them to environmental conditions rather than class, moral corruption, or genetics. Mr. Davenport suffers from "the fever" "(as it usually is in Manchester) of a low, putrid, typhoid kind; brought on by miserable living, filthy neighbourhood, and great depression of mind and body. It is virulent, malignant, and highly infectious" (61; ch. 6). Victorians understood by this time that typhoid was transmitted through contaminated food and water. By ingesting what they themselves put into the atmosphere, Manchester's residents infect themselves with their own filth. The trip to Berry Street further reveals miasma's permeability when George Wilson brings infection, an invisible "abomination," home: "The ghoul-like fever was not to be braved with impunity, and balked of its prey" (75; ch. 7). Wilson's twin boys contract the fever and Wilson dies shortly after, presumably a third victim. He could also potentially infect his employer, whom he visits to procure Davenport's medical order.

The scene moves from the Bartons's fairly tidy home to the Davenports's cellar, and then from this hovel to the luxurious drawing-room of the Carsons. As they eat a lavish breakfast, the Carson family remains blind to Wilson's hunger because, living a life of plenty 
themselves, they "forgot it was possible" another might be wanting (67; ch. 6). The diseased worker in their home is not enough to awaken the family from their complacency; this expresses Gaskell's own anxiety that the privileged classes cannot see the cause of dis-ease when they are in the midst of it. Gaskell's environmental politics should not be subordinated to her class politics as many critics have done and continue to do. In their influential work, Raymond Williams and Catherine Gallagher focus on environmental ills as symptomatic of the conflict between masters and men. Following Kathleen Tillotson's observation that what "really" shocked Gaskell's early readers was "the factual detail," Igor Webb insists that Mary Barton's "paramount feature" is its shock value: "More than any other work of literature, perhaps more than any other piece of writing in English, Mary Barton made known the condition of the mid-century working-class" (14). As Webb argues, Gaskell made her readers see class injustice; however, I assert that Gaskell exposes the upper-classes' own vulnerability to pollution, rather than simply showcasing dirt as another injustice suffered by the impoverished. She shows that pollution included both smog and waste, and renders visible that the factory owners rather than the multitude of hands that they employed were largely responsible for its production. I argue that attention to eco-consciousness reorients our basic understanding of major Victorian texts with respect to networks among all people, and networks between people and their communal environments. In short, everyone pollutes, and Gaskell focuses on class inequality because the poor lack the resources to defend against this pollution in which all classes are complicit.

Filth depresses both "mind and body", ${ }^{15}$ while Davenport succumbs to typhoid fever, his wife suffers from acute depression just as John Barton does after prolonged unemployment and having to move into smaller and smaller lodgings. Gaskell charges us to "[r]emember ... that though it may take much suffering to kill the able-bodied and effective members of society, it does not take much to reduce them to worn, listless, diseased creatures, who thenceforward crawl through life with moody hearts and pain-stricken bodies" (113; ch. 10). Even when pollution does not kill, it produces the dual sense of dis-ease: physical illness and mental anxiety. John Barton escapes typhoid but suffers from a "moody heart," or depression, brought on by filthy living conditions. His "infect[ious]" sadness demonstrates pollution's effect on overall well-being (98; ch. 10).

Gaskell intended John Barton to be her novel's protagonist, focusing on his inability to find work. The novel centers on his discontent and increasing dis-ease, suggesting that Barton is alienated both from work and from other people, and that he, his family, and co-workers are alienated from the natural world, which would provide some relief. In a pecuniary culture, Barton is his labor, and when he loses his place in the cotton-mill, he loses the wages necessary to support himself. Having no means to satisfy physical needs without purchasing goods, he will finally pawn most of his possessions to feed and clothe himself. Gaskell once again anticipates the work of Ruskin, whose later critique of industry dually condemns the "wealth" economy it necessitates, determining well-being by amassing large shares of commodities, in contrast to a "welfare" economy, meeting basic needs to ensure health and happiness. ${ }^{16}$ Gaskell favors a welfare economy, which is implied through John's ironic surname: "barton" means "farmyard" or, in a pre-industrial context, "threshing-floor," the clearing used by farmers to thresh and winnow the grain harvest before the advent of threshing-machines (OED). Gaskell suggests that Barton could provide for himself if he had access to arable land. Barton's enforced idleness and his urban imprisonment produce disease, symptomatic of the widespread environmental detachment creating a toxic economy 
and a toxic environment. The flaws of a capitalist economy gain significance as we consider Gaskell's attention to material goods and natural spaces. The ignorance of the sources of meals and clothes, characteristic of city-life in Gaskell's novel, signals a larger problem. This modernized landscape accounts for pollution in that the Victorians feel so divided from the environment that they cannot conceive of the consequences of their actions. By diagnosing dis-ease - ill-being that accounts for mental malaise - the novel reveals a more prevailing condition than apparent physical illness.

Gaskell strategically idealizes the country by emphasizing the toxicity and dis-ease associated with city living. Readers of Victorian novels will recognize the trope contrasting the pure countryside with the polluted city. ${ }^{17}$ Barton's dis-ease results from his alienation from the natural world as much as his unemployment. The opening scene in Green Heys Fields sets the tone for the novel as Gaskell suggests rural influences must be preserved to ensure good health. ${ }^{18}$ We see the townspeople seeking open space for repose:

\footnotetext{
Here in their seasons may be seen the country business of haymaking, ploughing, \&c., which are such pleasant mysteries for townspeople to watch; and here, the artisan, deafened with the noise of tongues and engines, may come to listen awhile to the delicious sounds of rural life: the lowing of cattle, the milkmaid's call, the clatter and cackle of poultry in the old farmyards. $(5 ; \mathrm{ch} .1)$
}

Matters of subsistence are "mysteries" to the townspeople, surrounded by stone and smoke. Gaskell suggests that industry "deafen[s]" and blinds urban denizens to their role in the ecosystem. The workers enjoy the respite Green Heys Fields provides from their city environment, while reducing the essential business of living, growing food, into an "\&c." The townspeople likely import most of their crops, milk, cheese, and meat from these fields on the southernmost edge of the city. Though indicating that Manchester's denizens feel discontent in the chaotic city, this scene also illustrates how disconnected they are from the land and the significance of these tasks. The moodiness pervading the novel is tied to this first scene, which shows on one hand that people continue to seek nature and on the other how alienated they are from it. Gaskell contrasts the "sallow complexions" of urban laborers with their rural counterparts, suggesting the power of fresh air to improve health and alleviate drudgery. Williams, who claims Mary Barton "is the most moving response in literature to the industrial suffering of the 1840s" (Culture and Society 87), argues that these early chapters "embody the characteristic response of a generation to the new and crushing experience of industrialism" (88). The country/city trope invokes the divide between land-based agrarianism and capitalistic industrialism, or, alternatively, between health and dis-ease. Though Gaskell enlists pastoral support, her emphasis on labor and subsistence rather than leisure reorients readers' perspectives from the superficial acknowledgement of cleanliness and spaciousness to the necessary conditions of health, maintaining the ecosystem. One should not have to leave the city to breathe fresh air, she suggests. This eco-consciousness posits solutions to the pressing questions of the social problem novel: agrarianism would ennoble labor and emphasize communal environmental engagement as a palliative to the industrial condition.

The first chapter's pastoral demonstrates the dissociation between consumers and suppliers, which generates dis-ease. Gaskell comes close to idealizing the fields in her effort to reveal the impact of pollution, but importantly, she remains optimistic about the possibility of sustainable living in the city, characteristic of eco-consciousness. In contrast 
to this industrial economy, Alice Wilson and Job Legh represent an alternative agrarian ethos as their environmental engagement builds community. ${ }^{19}$ Each character becomes a source of support for her/his neighbors, a sage who can cure and calm. Alice represents a type of economy that keeps nature and work together, and, crucially, can exist within urban environments. She retains local knowledge of homeopathic herbs. By knowing what to look for, she can spot useful plants throughout the city as well as in the fields, ministering cures to her neighbors that are more effective than the products sold by apothecaries. ${ }^{20}$ Despite hardship, her meaningful contact with the community inoculates Alice to depression. We see, then, that Gaskell does not simply call for a retreat into the country; rather, the conditions that make the country healthy ought to be replicated throughout England. Similarly, Job, the naturalist, eagerly familiarizes himself with his surroundings, collecting plant and animal specimens that keep him "happy" and "pleased" (42; ch. 5). His hobby trains him to be a careful observer, allowing him to mediate the conflict between masters and men. Job teaches the novel's characters and readers to "see" the artificiality of class distinctions. This lesson in equality engenders sympathy and the eco-consciousness that all human beings are equally susceptible to pollution. If miasma can travel from Berry Street to Ancoats, it can infect anyone, anywhere. Reforming the slums safeguards the health of the nation.

In a sudden break from her narrative, Gaskell describes the view from her window which she writes beside: "a lovely night in the country," so different from the scene of her novel (246; ch. 22). "[T]he rustling air makes music among their branches, as if speaking soothingly to the weary ones, who lie awake in heaviness of heart. The sights and sounds of such a night lull pain and grief to rest" (246; ch. 22). Suffering exists in the country, but the pastoral environment's influence has the power to alleviate its symptoms. Coming during Mary's anxious efforts to exonerate her lover, Jem, this breath of fresh air diffuses the novel's intensity and represents what Gaskell hoped the result of her novel would be: the power of eco-consciousness, listening to the signs of the environment, to "lull pain and grief," or dis-ease, "to rest." This moment of narrative relief joins the larger expressive economy of dis-ease, an active set of narrative strategies that Gaskell uses to resolve real-world issues.

\section{Beyond Beauty: Rural Toxicity}

THOUGH GASKELL's ATTENTION TO TOXICITY may feel well rehearsed by literary critics, an awareness of her eco-consciousness helps to unveil Brontë's use of the same ideology in Jane Eyre and forces a reconsideration of standard Victorian tropes. While Gaskell uses the fields to emphasize urban risks, Brontë challenges the myth of the countryside, showing the indiscriminate reach of filth. "Everywhere," as Ruskin insists, human beings harm the atmosphere with "foul" chemicals. Autobiographical elements of Jane Eyre have been widely examined, and looking at Brontë's upbringing in the polluted village of Haworth helps us understand her awareness of the connection between health and habitat. In his "series of sketches" of famous nineteenth-century women, James Parton observes, "They [the three sisters] were reared amid surroundings the most gloomy and unhealthful," concluding, "[t]heir very genius seemed a product of disease" (28). Parton refers to the wildness of the moors and the loneliness of the parsonage, indicating their genius might result from some sort of peculiar mental disease; however, the adjective "unhealthful" becomes quite literal when we take into account their proximity to the parish graveyard and the lack of sufficient 
and clean water. Their genius was not simply a product of disease but Ruskinian dis-ease, unhealthful of mind and body because of exposure to environmental toxicity.

Benjamin Herschel Babbage, in his report to the General Board of Health in 1850, based on his visit in April 1849, exposes the grave sanitary situation in Haworth:

\begin{abstract}
There are no sewers . . ; a few covered drains have been made in some of the streets to carry away the surface water . . . but generally the drainage runs along in open channels and gutters. As a necessary consequence of the want of sewerage there is contiguous to each privy a receptacle for the night soil ...; into these midden-steads are thrown the household refuse and the offal from the slaughter-houses, where, mixed with the night soil, and occasionally with the drainage from pigsties, the whole lies exposed for months together, decomposition goes on and offensive smells and putrid gases are given out. These midden-steads are uncovered, and the majority of them were nearly full when I examined them. Bad as they are, their situation, in close proximity to dwelling-houses, makes them much more injurious. (13)
\end{abstract}

Babbage's report exemplifies eco-consciousness in his attempt to expose the sources of rural toxicity and the dangerous combination of factors at work. Miasmic language identifies the "offensive smells" and airborne matter that infects Haworth's residents; however, this document demonstrates the rhetorical and conceptual postures of dis-ease as Babbage explains how human beings create miasma by "mixing" together household waste and excrement, keeping these receptacles "uncovered" and overflowing. It would seem obvious that this ignored and untended waste would create injurious conditions. The sheer lack of basic preventative waste management typifies dis-ease. This is the state of Haworth as Brontë composed Jane Eyre. Babbage's description strikingly resembles Gaskell's portrayal of the Davenports' hovel in Manchester: open gutters, pigsty refuse, and filth festering for months. ${ }^{21}$ He refers to the noxious miasma contaminating Haworth's atmosphere, also observing that the hamlet's "common earthen pot-pipes" leaked large quantities of water while absorbing environmental contaminants, allowing fecal matter and effluvia from decomposing bodies in the overcrowded hill-top cemetery to seep into the soil. Babbage reports 1,344 burials in the churchyard in the ten years between 1840 and 1850 (19). ${ }^{22}$ Thus, one can accurately say that the Brontës drank water contaminated with corpses. Clearly the siblings were no strangers to filth. These considerations arise in the Lowood portion of the novel, which recalls the unsanitary conditions of Cowan Bridge, a Clergy Daughters School in Lancashire. As Gaskell chronicles in The Life of Charlotte Brontë (1857), Charlotte's elder sisters, Elizabeth and Maria, died of tuberculosis in 1825 due to the school's unhealthiness. ${ }^{23}$ The biography of the Brontë family depicts Victorian rural dis-ease as powerfully as their fiction.

Jane Eyre employs miasmic language to expose the causes of the typhoid epidemic at Lowood Institution in rural Lancashire, particularly emphasizing the rural population's blind eye to environmental contamination. Significantly, Jane is orphaned when her parents succumb to typhus fever "while visiting among the poor of a large manufacturing town" (35; ch. 3). When the novel opens at Gateshead, Jane is relieved that inclement weather prevents "the possibility of taking a walk that day" $(13 ;$ ch. 1$){ }^{24}$ While Jane dislikes winter walks in the novel's opening, she begins to appreciate the fresh air of spring when banished to Lowood. After describing the "prospect of noble summits girdling a great hill-hollow, rich in verdure and shadow; in a bright beck, full of dark stones and sparkling eddies" (88; ch. 9), she asks, "Have I not described a pleasant site for a dwelling, when I speak of it as 
bosomed in hill and wood, and rising from the verge of a stream? Assuredly, pleasant enough: but whether healthy or not is another question" (89; ch. 9). Jane "question[s]" the pastoral assumption that beauty equates purity in terms of health. She intends to shock the reader by revealing that Lowood lay in a "cradle of fog and fog-bred pestilence; which, quickening with the quickening spring, crept into the Orphan Asylum, breathed typhus through its crowded school-room and dormitory, and, ere May arrived, transformed the seminary into a hospital" (89; ch. 9) ${ }^{25}$ The fictional name, "Lowood," reinforces its location as low in the valley, near the river, believed to create such conditions. We should not read this section merely as a critique of hypocritical charity; miasmic language alerts us to certain tropes, such as the "fog-bred" pestilence and poorly drained soil near the river. Though her invocation of miasma theory suggests she shared the common understanding of how contagion was spread mid-century, Brontë accurately traces the cause of disease to toxic effluvia.

Jane notes the epidemic takes hold in May. Spring, in fact, is a sinister season, awakening not only healthful plant life but also bacteria and virulent organisms. Despite its beauty and sweet smells, Lowood is a hotbed of disease. Rural areas were often slowest to reform, especially because of their idyllic appearance. Brontë warns against such complacency as Jane shatters this illusion, demonstrating the main idea of germ theory: appearances are deceiving; one cannot see or smell germs. While Bronte refers to a "fog-bred pestilence" since terms such as "pathogens" and "microorganisms" would not enter the lexicon until well-after germ theory's introduction during the last two decades of the century, like Gaskell, she attempts to articulate that an appearance of cleanliness does not guarantee health or prevent illness. The fog's movement suggests that the infection originated from the town and has blown over to this rural area. Lowood sits on an "unhealthy" site, and arguably "swampy" surroundings could generate this fog. However, in her autobiography of Brontë, Gaskell argues strongly against the fact that the school was built on bad ground, though she calls the area "damp" (55), instead explaining that illness spreads easily when people live "in close proximity" and sanitary principles are not understood (53). As we saw in Mary Barton, Gaskell's use of "damp" often means "unhygienic." Given her account, we may interpret Brontë's explanation of the epidemic in Jane Eyre not as an affirmation of miasma theory, but as an amateur's comprehension of germ theory. However, the importance lies in Brontë's concern about diseases transmitted by pollution. The narrative makes clear that the fog travels into Lowood and does not arise from there, illustrating permeable borders. Though Cowan Bridge ("Lotown") itself was very rural, the numerous factories in Lancashire country severely polluted the landscape. ${ }^{26}$ Fog may then indicate "smog" or miasma from sewage flushed downstream, towards rural outskirts. The dampness of "poorly drained soil" is not particularly dangerous until we understand the river's relationship to the larger towns. Lowton's river is likely the Lune. Though touted for its beauty and purity, the river was just as polluted as any other, with untreated sewage dumped into the river as late as 1900. Jane notes the "fetid water" used by the school, drawn from this contaminated river. These circumstances emphasize the environmental factors of disease and the possibility of faraway residents polluting rural places. ${ }^{27}$ While Gaskell assumes in her account of Cowan Bridge that, like the slums about which she writes, overcrowding and human filth have the greatest effect, Brontë demonstrates a greater link between human health and environmental contamination by showing not just how people within a city or town are affected but how filth from one town can affect another location entirely. Developing many of the concerns of urban fiction, Brontë's rural vision moves between geographic spaces as well as between classes. 
Brontë differentiates between the evil one can see - stagnant pools, smog - and the evil that remains hidden - germs, chemical contaminants -, an eco-conscious narrative strategy that renders visible how humans' mistreating the environment ignores the essential need for its sustenance. The weakened constitutions of the children make them increasingly susceptible to environmental contaminants. Lowood is indisputably both polluted and neglected, a deadly combination. The virulence of the disease brings unwanted attention on the school, resulting in a thorough investigation: "by degrees various facts came out which excited public indignation in a high degree. The unhealthy nature of the site; the quantity and quality of the children's food; the brackish, fetid water used in its preparation; the pupils' wretched clothing and accommodations: all these things were discovered" ( 97 ; ch. 10). Though the school is moved to a "better situation" ( 97 ; ch. 10), Brontë implies that had administrators been better informed (or more humane), the situation could have been prevented. She shifts the blame in creating toxicity from organically damp ground to human agency. Historical distance serves to provide a narrative solution to the real world problem of environmental detachment in the present. The epidemic generates awareness just as the novel, by reporting the event for readers twenty years later, intends to encourage eco-consciousness. Brontë's historical non-specificity distinguishes her method from Gaskell's in that Jane Eyre's activism transcends time. Instead of couching this social problem in a contemporary industrial context, Brontë critiques the persistent prevailing mentality that separates humans from their environment.

Questions of where and how to live inform the novel as a whole, influencing even the hidden "madwoman in the attic" so central to the novel. Rochester houses Bertha at Thornfield Manor because he deems his other residence, his hunting lodge Ferndean Hall, unfit due to bad air and damp walls. Similarly with Lowood, Ferndean also describes its atmosphere as a muggy, secluded wood. Although English ferns grow in a variety of habitats, the most common species thrive in moist, shady forests - the kind of humid conditions believed to engender miasma. Rochester, with mixed motives of compassion and concealment, prefers to keep his wife under his own care, rather than entrust her to the madhouse or with a servant at Ferndean, where he cannot ensure her good health. He tells Jane, "I could have lodged her safely enough [in Ferndean Manor], had not a scruple about the unhealthiness of the situation, in the heart of a wood, made my conscience recoil from the arrangement. Probably those damp walls would soon have eased me of her charge" (300; ch. 27). Rochester subscribes to the prevailing misconception that organic vapor compromises health, and this common fear makes it impossible to rent the "ineligible and insalubrious site" (430; ch. 36). When he is forced to relocate to Ferndean after the destruction of his primary residence, Rochester must learn how to live there. While Rochester assumes Ferndean's uncomfortable dampness signifies toxicity, the environment is cleaner than Lowood, whose beauty masks toxicity.

The gloom impresses Jane when she first visits Ferndean; she, too, wonders how life can exist in this dense and dark wood and momentarily experiences dis-ease. The lodge, almost indistinguishable from the trees, stands in the woods with "no grounds," "no flowers, no garden-beds," "only a broad gravel-walk" (430; ch. 36). Unlike the property of a traditional English estate, the area is almost authentically wild: it has not been "improved" or cultivated. Once Jane reconciles with Rochester, she awakes to a "bright, sunny morning" (439; ch. 36). This does not reflect Jane's better mood so much as a new way of looking at the place due to her desire to make a home there. Until Rochester's sight is restored, she becomes his 
eyes: "I was then his vision. . . . He saw nature . . through me; and never did I weary of gazing for his behalf, and of putting into words the effect of field, tree, town, river, cloud, sunbeam - the landscape before us; of the weather round us" (451; ch. 38). When she must interpret the scene for her husband, Jane adopts a naturalist's gaze. She sees not only the loveliness of the scene, but also the "effect of" the weather "round" them, an articulation of the environment's material influence. She also discerns the town, recognizing a human presence within the environment. As she looks carefully at her surroundings, the details lose their foreboding aspect. Beyond the "wild wood" are "cheerful fields," "brilliantly green" with "refreshed" flowers, under a "sparklingly blue sky" (439; ch. 37). Jane's language now suggests the healthiness of the place and its ability to reinvigorate Rochester. As they settle into the area, spending most of their time in "the open air" (439; ch. 37), nature becomes a part of their daily existence, bringing health and clarity. Like the breath of fresh air offering a momentary reprieve in Mary Barton, the couple let in Ferndean's atmosphere. The place has not changed; rather, the way they perceive the place has changed. The mist clears away from their sight, dispelling the fallacy that the muggy site breeds disease, and they see the land as it is. Brontë implies the wildness of the wood is off-putting, but, through keen vision that sees the actual environment, the pair flourishes.

The way Jane and Rochester interact with the space fundamentally differs from its earlier use as a hunting-lodge. Jane notices the "game covers," which tell of the property's original history (430; ch. 37). Visiting Ferndean to hunt, Rochester once dominated the environment; he kills for sport the creatures that call the place home. However, once Rochester marries Jane, together they coexist with nature, raising a family and properly dwelling there. ${ }^{28}$ Communion with the environment renders it healthy. Rochester might initially assume that living at Ferndean will lead to death, but living there cures his dis-ease. The couple cultivates a good, clean household. Ferndean's dampness is not the same unhygienic dampness polluting Lowood. These portions of the novel contrast organic rankness and the industrial, man-made miasma which leads to the death of so many girls. Lowood's miasma emerges from the fetid, sewage-filled water and industrial fumes. Prefiguring the scene in Berry Street, the human body absorbs the pollution it creates. Lowood casts a death sentence, not because the site is inherently toxic, but because neglect and recklessness make it so. "Fog" or "vapor" only becomes fatal "miasma" when human beings introduce toxicity into the atmosphere. Jane breathes fresh air ("Eyre") into Ferndean when she arrives to nurse Rochester, clearing away cultural assumptions about the wild wood. When they successfully make a home there, Brontë implies that the place is not uninhabitable or even toxic at all. Through discourse, the novel encourages eco-conciousness in its reader, the ability to see hidden realities. The effort to coexist within the ecosystem, which includes conserving resources, proper waste management and curtailing dangerous emissions, reduces the threat of toxicity. As ecoconsciousness compels readers to recognize and recover from dis-ease, Jane breaks free of faulty vision. By learning to see the landscape properly, Jane becomes a part of it.

Moving through the urban to rural novel reveals the ideology behind discursive activism, by making the pervasive, but often unacknowledged, risks of pollution readable. The focus on urban toxicity in Victorian studies may blind us to the larger discourses of eco-consciousness and dis-ease. Pairing these novels offers two complementary views of filth - the smoky, slopfilled city and the equally toxic countryside -, and offers a vision of health in identifying and reversing the perceived separation between humans and the environment that creates dis-ease and disease. These Victorian novels do what legislation failed to do by stimulating 
awareness and the appetite for change, creating an enduring eco-consciousness to mobilize activism.

\section{Stony Brook University}

\section{NOTES}

1. Carpenter would adopt this ideology to promote socialism, particularly in Civilisation, its Causes and Cure (1889).

2. Gaskell's novel provides an example of what Choi calls "risk" fiction, an urban subgenre born out of the burgeoning public health movement in the 1840s and 1850s that responds to the pervasive threat of environmental toxicity in the city. Novels such as Mary Barton insist on "the ubiquity and unavoidability of urban filth and disease-generating miasma," revealing for a middle-class readership that to be "at risk" is the "inevitable condition of urban life" (562).

3. History credits Louis Pasteur, Ferdinand Cohn, and Robert Koch with discovering and perpetuating germ theory. When Koch used a microscope to identify the bacterium Vibrio cholerae in 1883, he revealed that many infectious diseases are caused by microorganisms that are invisible to the naked eye and invade the body.

4. Though Buell counts Victorian authors among his examples, particularly Dickens, others following him focus more on toxic discourse in contemporary fiction and film.

5. While certain movements, particularly sanitation reform, acted to improve living conditions at midcentury, Victorians were slow to participate in environmental activism (concerted protest pursuing political and social agendas) until Victorian literature and other print media pressured government and interest groups to reform and enforce legislation. This pressure indicates an earlier awareness of ecological problems than scholars typically credit to the period and illustrates the power of the novel in voicing a moral imperative as a vehicle for social change.

6. In "Eco-Conscious Synaesthesia: Dirt in Kingsley's Yeast and Alton Locke," I explore the technique of eco-conscious synesthesia in detail.

7. Gaskell's letters also reveal her preoccupation with Manchester's deleterious effect on her health; she frequently sought fresh, country air, admitting to Lady Kay-Shuttleworth,"I would fain be in the country, - \& last experience of country air has done me so much good - I am a different creature to what I am in Manchester" (139).

8. By 1850, the novel required a fifth edition, which Gaskell urged her publishers to make affordable to the working classes.

9. Parham similarly traces the interconnections between human beings with both each other and their surrounding physical environment; however, he does not specifically analyze the discursive similarity between Condition of England novels that not only raises awareness in middle-class readers, but also gives them the vocabulary and evidence to mount real-world reform.

10. Interestingly, Ruskin connects the "loathsome mass of sultry and foul fog, like smoke" moving through Brantwood with "Manchester devil's darkness," implying the pollution of the Lake District originates from the manufacturing districts $(55,56)$.

11. Unlike fog, which occurs naturally, smog denotes the mixtures of smoke and fog. The term was coined when Dr. H. A. des Vœux, treasurer of the Coal Smoke Abatement Society, read a paper to the Public Health Congress of Great Britain on "Fog and Smoke" in July of 1905. The Daily Graphic (26 July 1905 ) reported, "He said it required no science to see that there was something produced in great cities which was not found in the country, and that was smoky fog, or what was known as 'smog"' (qtd. in OED). 
12. Guy posits that a social problem is caused by social structures as opposed to problems in society, which arise when individuals fail to control their behavior.

13. See Cohen, for a fuller discussion of these terms.

14. Freeland asserts, "Novels such as Mary Barton and Ruth ... reveal that a misplaced obsession with cleanliness, and the entire domestic ideology it underwrites, are at best irrelevant in the face of larger social problems" (812). Freeland argues the good intentions of sanitary reformers are misplaced; a little dirt masks deeper economic inequalities that need to be addressed and that Gaskell did not regard dirt as the most pressing social problem. However, Gaskell is not merely concerned with "dirt" as the Berry Street scene illustrates. I argue here that rendering refuse and squalor visible was precisely the method of revealing pollution as a social problem that impacted the poor most severely.

15. Haley explains, "Total health or wholeness - mens sana in corpore sano - was a dominant concept to the Victorians, as important in shaping thought about human growth and conduct as nature was to the Romantics" (4). As the Latin motto indicates, mental and physical health were believed to be dependent on one another.

16. For a discussion of these two economies, see Gagnier.

17. In The Country and the City, Williams explains how the countryside was often idealized in service of promoting traditional, natural, unadulterated values, in contrast to the city, the site of modernism, social disorder, and vice.

18. In his assessment of the novel's historical accuracy, Bland focuses on the novel's opening in Green Heys Field, considering the likelihood of rural spaces being available to workers in Manchester in the late 1830s. Gaskell's contemporaries refuted her suggestion that the laboring classes sought the countryside. Bland concludes that the opening scene does in fact give "an accurate picture of one of the more innocent recreations of the Manchester operative of the 1830's" (60). His research verifies the accuracy of Mary Barton and interestingly shows how threatened rural areas actually were, so much so that Victorian readers were skeptical that a field would remain at all within walking distance of the city.

19. For fuller discussions of Job's role in the novel, see King, Coriale, and Secord.

20. Alice is continually called upon for her alternative medicine. Haley lists some of the hack cures sold in apothecary shops which sold "hundreds of 'specifics,' drugs intended to attack particular varieties or symptoms of disease. Among the remedies for 'hooping-cough' . . . were opium, belladonna, digitalis, bark, cup moss, arsenical solution, nitrate of silver, oil of Amber, meadow narcissus, and acetate of lead" (13). Barton purchases one of these expensive and ineffective tonics for his son in chapter 3.

21. In the small population of approximately 2,600 in Haworth, the average age of death was 25 , and the mortality rate of children under six was 41 percent $(7,10,12)$. Babbage notes that one privy served every 4.5 houses (11).

22. In her accounts of Haworth, Gaskell more than once refers to the unhealthy atmosphere, in one letter noting the "pestiferous churchyard" just outside the parsonage windows (Letters 242). Patrick Brontë, who aided Babbage in compiling his report, recognized that this filth was not something that should be tolerated and attempted to teach the health risks resulting from unhygienic environments. Ellen Nussey discusses his zeal for sanitary reform, narrating one particular mission: convincing the women of his parish to cease washing their clothes and hanging them up to dry in the cemetery. She reprints a humorous poem Patrick wrote for the occasion where he disgustingly describes the moaning corpses swimming in suds; although he intends to remonstrate against the violation of their slumber, the accompanying image of the women standing on damp, fetid ground is visceral and disturbing, showing harm to both the living and the dead.

23. Helen Burns, Jane's friend, closely resembled Maria who was reportedly persecuted at the school. Her last name may suggest her internalization of the criticism of Brocklehurst and her teachers, who predict she will burn in hell-fire for her slovenly, lazy ways. However, her name also intimates the burning of her fever and her painful suffering from consumption. 
24. Burkhart notes that "nature" is a "key word" in Jane Eyre, appearing "frequently and climactically," designating "right" action or "feeling." The word serves "as a guide" to the conflict between reason and feeling, and Burkhart argues that the novel is most rich and graceful when describing physical nature (178). He concludes that her "simple" belief in nature places Charlotte, spiritually, with the Romantics (178). However, as he shows, Brontë is conscious of natural law and the consequences of violating our inner natures and ignoring physical nature. Duthie points to a system of "objective correlatives" created through a figurative scheme of natural elements: air, water, earth, and fire. Each of the novel's five settings align with important stages in Jane's life. Her work shows "the organic link between her experience and the landscapes" (134), highlighting nature's figurative function, whereas I am concerned with the literal consequences of these settings.

25. That Brontë calls the disease "typhus" signals her ignorance; she seems to mean typhoid, carried in contaminated food and water. Typhus, a parasitic bacteria, could only be transmitted through living organisms, like lice and fleas.

26. By the 1830s, $85 \%$ of the world's cotton was manufactured there (Gibb 13), a fact contemporary readers would recognize.

27. In the intervening two decades between Brontë's childhood and the publication of her novel, not much had changed in England as a whole. Brontë's eco-consciousness applies to current conditions, where industrial miasma becomes increasingly probable.

28. I invoke the Heideggerian definition of "dwelling" as building a life rooted to a specific place.

\section{WORKS CITED}

Babbage, Benjamin Herschel. Report to the General Board of Health on a preliminary inquiry into the sewerage, drainage, and supply of water, and the sanitary condition of the inhabitants of the hamlet of Haworth. London: W. Clowes \& Son, 1850.

"barton, n.1." OED. Oxford UP, 2012.

Berry, Wendell. "Health as Membership." The Art of the Commonplace: The Agrarian Essays of Wendell Berry. Ed. Norman Wirzba. Emeryville: Shoemarker \& Hoard, 2002. 144-58.

Bland, D. S. "Mary Barton and Historical Accuracy.” Review of English Studies, New Series 1.1 (Jan. 1950): $58-60$.

Briggs, Asa. Victorian Cities. Berkeley: U of California P, 1993.

Brontë, Charlotte. Jane Eyre. Ed. Michael Mason. London: Penguin, 1996.

Buell, Lawrence. Writing for an Endangered World. Cambridge: Belknap, 2001.

Burkhart, Charles. "Another Key Word for Jane Eyre." Nineteenth-Century Fiction 16.2 (Sept. 1961): $177-79$.

Carpenter, Edward. Civilisation, its Cause and Cure, and Other Essays. London: Swan Sonnenschein, 1908.

Choi, Tina Young. "Writing the Victorian City: Discourses Of Risk, Connection, And Inevitability." Victorian Studies: An Interdisciplinary Journal Of Social, Political, And Cultural Studies 43.4 (2001): 561-89.

Cohen, William A. "Introduction: Locating Filth." Filth: Dirt, Disgust, and Modern Life. Ed. William A. Cohen and Ryan Johnson. Minneapolis: U of Minnesota P, 2005. vii-xxxvii.

Coriale, Danielle. "Gaskell's Naturalist." Nineteenth-Century Literature 63.3 (2008): 346-75.

Dickens, Charles. Bleak House. Ed. Nicola Bradbury. London: Penguin, 2003.

Disraeli, Benjamin. Sybil, or, the Two Nations. Ed. Sheila M. Smith. Oxford: Oxford UP, 2008.

Duthie, Enid L. The Brontës and Nature. New York: St. Martin's, 1986.

Eliot, George. Adam Bede. Ed. Carol A. Martin. Oxford: Clarendon P, 2001.

Freeland, Natalka. “The Politics of Dirt in Mary Barton and Ruth." SEL 42.4 (Autumn 2002): 799-818.

Gagnier, Regenia. The Insatiability of Human Wants: Economics and Aesthetics in Market Society. Chicago: Chicago UP, 2000. 
Gallagher, Catherine. The Industrial Reformation of English Fiction: Social Discourse and Narrative Form, 1832-1867. Chicago: U Chicago P, 1985.

Gaskell, Elizabeth. The Letters of Mrs. Gaskell. Ed. J. A. V. Chapple and Arthur Pollard. Cambridge: Harvard UP, 1967.

Gaskell, Elizabeth. The Life of Charlotte Brontë. Ed. Elisabeth Jay. London: Penguin, 1997.

Gaskell, Elizabeth. Mary Barton. Ed. Macdonald Daly. London: Penguin, 2003.

Gibb, Robert. Greater Manchester: A panorama of people and places in Manchester and its surrounding towns. London: Myriad Books, 2003.

Guy, Josephine M. The Victorian Social-Problem Novel: The Market, Individual and Communal Life. New York: St. Martin's, 1996.

Haley, Bruce. The Healthy Body and Victorian Culture. Cambridge: Harvard UP, 1978.

Kennedy, Margaret S. "Eco-Conscious Synaesthesia: Dirt in Kingsley's Yeast and Alton Locke." Victorian Network 6.2 (Winter 2015): 59-85.

King, Amy Mae. "Taxonomical Cures: The Politics of Natural History and Herbalist Medicine in Elizabeth Gaskell's Mary Barton." Romantic Science: The Literary Forms of Natural History. Ed. Noah Heringman. Albany: SUNY P, 2002.

Metropolitan Sewage Committee proceedings. Parliamentary Papers, 1846, vol. 10.

Nussey, Ellen. "Reminiscences of Charlotte Brontë by 'a schoolfellow'." The Letters of Charlotte Brontë. Vol. One, 1829-1847. Ed. Margaret Smith. Oxford: Clarendon P, 1995: 589-610.

Parham, John. '“For You, Pollution.' The Victorian Novel and Human Ecology: Benjamin Disraeli’s Sibyl and Elizabeth Gaskell's Mary Barton." Green Letters: Studies in Ecocriticism 14.1 (2011): 23-38.

Parton, James. Daughters of Genius. Philadelphia: Hubbard Brothers, 1887.

Ruskin, John. "Of Kings' Treasuries." Unto this Last and Other Writings. Ed. Clive Wilmer. London: Penguin, 1997: 255-87.

Ruskin, John. "The Storm-Cloud of the Nineteenth Century.” Kent: George Allen, 1884.

Ruskin, John. "The White Thorn Blossom." The Genius of John Ruskin. Ed. John D. Rosenberg. Charlottesville: U of Virginia P, 1998: 362-73.

Secord, Anne. "Elizabeth Gaskell And The Artisan Naturalists Of Manchester." Gaskell Society Journal 19 (2005): 34-51.

"smog, n." OED. Oxford UP, 2012.

Thorsheim, Peter. Inventing Pollution: Coal, Smoke, and Culture in Britain since 1800. Athens: Ohio UP, 2006.

Tillotson, Kathleen. Novels of the Eighteen-Forties. Oxford Paperbacks. London: Oxford UP, 1961

Webb, Igor. Rereading the Nineteenth Century: Studies in the Old Criticism from Austen to Lawrence. New York: Palgrave Macmillan, 2010.

Williams, Raymond. The Country and the City. New York: Oxford UP, 1973.

Williams, Raymond. Culture and Society, 1780-1950. New York: Columbia UP, 1983.

Wohl, Anthony S. Endangered Lives: Public Health in Victorian Britain. London: J. M. \& Sons, 1983. 